Man and Nature

MAN AND NATURE

L'homme et la nature

L'HOMME ET LA NATURE

\title{
The Physico-Theological Epic in the Later Eighteenth Century
}

\section{H. Grant Sampson}

Volume 2, 1984

URI : https://id.erudit.org/iderudit/1011811ar

DOI : https://doi.org/10.7202/1011811ar

Aller au sommaire du numéro

Éditeur(s)

Canadian Society for Eighteenth-Century Studies / Société canadienne d'étude du dix-huitième siècle

ISSN

0824-3298 (imprimé)

1927-8810 (numérique)

Découvrir la revue

Citer cet article

Sampson, H. G. (1984). The Physico-Theological Epic in the Later Eighteenth Century. Man and Nature / L'homme et la nature, 2, 49-60.

https://doi.org/10.7202/1011811ar
Résumé de l'article

L'élaboration et la défense des sytèmes religieux chrétiens étaient plus importants dans la poésie anglaise du $18^{\mathrm{e}}$ siècle que la plupart des lecteurs modernes ne pensent. Environ cent poèmes de longueur considérable étaient consacrés à ce sujet. Dans les termes proposés par la science contemporaine, ils élaborent des démonstrations de l'existence de Dieu à partir du monde créé par lui, et ils font valoir la justice de Dieu envers les hommes.
Copyright (C Canadian Society for Eighteenth-Century Studies / Sociéte canadienne d'étude du dix-huitième siècle, 1984
Ce document est protégé par la loi sur le droit d'auteur. L'utilisation des services d'Érudit (y compris la reproduction) est assujettie à sa politique d'utilisation que vous pouvez consulter en ligne.

https://apropos.erudit.org/fr/usagers/politique-dutilisation/ 
THE PHYSICO-THEOLOGICAL EPIC

\title{
IN THE LATER EIGHTEENTH CENTURY
}

\author{
H. Grant Sampson
}

The eighteenth century witnessed the publication of a group of poems-perhaps the total number is close to one hundred--which in varying ways are concerned with the structure of the universe and man's place in it. For evidence concerning this grand system of order the poets drew upon the discoveries which contemporary science had been making. To them there was no substantial conflict between the evidence of science and the truths of religion, and so they were able to produce descriptions of a harmony which, if made less than viable by man's fallen nature, was at least an important ideal for man's happiness.

As Fairchild pointed out comprehensively in the 1940 s and as other scholars have subsequently examined in somewhat greater detail, 1 religious--even theological--concerns continued to provide the subject matter for English verse throughout the eighteenth century. Many of the longer poems are deliberately modelled upon the traditional epic: they are extensive in length, running to several books; they are extensive in scope, presuming to explore the design of the universe; they are extensive in philosophy, claiming to vindicate the ways of God to man. Many of them contain formal elemnts of the epic: the Invocation, the Statement of Theme, the Heroic Speech. Because of these characteristics they can conveniently be called epics, although generically they may more properly be identified as verse epistles or extended odes. This type of epic, expounding physico-theological ideas, was written in every decade of the century; 
some of those written in the earlier decades are familiar to scholars, but it is important to recognize that physico-theological epics continued to be produced and to receive attention long after the "Romantic Movement" shifted the poetic focus to more personal matters.

These poems are moral and didactic in intention. They are the sort of writing which Joseph Warton had in mind when he complained in the Advertisement to his Odes on Various Subjects (1746) that "the fashion of moralizing in verse has been carried too far." They also represent the rationalizing and systematizing mentality which William Blake attacked in The Marriage of Heaven and Hell (etched c. 1793):

The ancient Poets animated all sensible objects with Gods or Geniuses......till a System was formed, which some took advantage of, and enslaved the vulgar by attempting to realize or abstract the

Mental Deities from their objects: thus began Priesthood.

These are the works in contrast with which William Wordsworth in the Preface to Lyrical Ballads (1802) called his volume of poems "an experiment."

But also they are poems in the tradition of Milton's Paradise Lost and Pope's An Essay on Man, because--as Blake said of his own poem Milton--they claim "to justify the ways of God to man." A number of these works directly concern themselves with this topic and, in fact, incorporate that phrase; all of them are at least indirectly concerned with Providence as they focus upon some particular aspect of the system of the universe.

The extent of this group of poems is enormous. Some, like Milton's Paradise Lost (1667), Thomson's The Seasons (1726-30), and Young's The Complaint: or, Night Thoughts (1742) are well-known and have received critical attention. ${ }^{2}$ Others, like Akenside's The Pleasures of Imagination (1744), Cowper's The Task (1785), Warton's The Enthusiast (1748), and Smart's Song to David (1763) are well-known but have been studied within some other context. Poems like Cooper's The Power of Harmony (1745), Brooke's Universal Beauty $(1735-36)$, Browne's An Essay on the Universe (1739), Mallet's The Excursion (1728), and Savage's The Wanderer (1729) are known to specialists in the area, whereas a number of poems, such as Portal's Innocence (1762), Blackmore's The Nature of Man (1711) and his Redemption (1722), Downman's Infancy (1775-76), and Wise's The System (1781) seem to be virtually unknown.

Unfamiliarity with this group of poems is regrettable because, although few of them can boast passages of poetic merit of the kind Warton, Blake, or Wordsworth demanded, they were works which very much fulfilled a demand for a certain type of poetic expression throughout the period. They are of interest to the scholar, therefore, in several ways. For the historian of ideas they provide a comprehensive index to many of the fundamental religious and social concerns of the century. For the literary historian they represent a major poetic tradition which, however strongly rejected by some later writers, did incorporate not only Paradise Lost and An Essay on Man, but also In Memoriam and The Testament of Beauty. For the critic these poems illustrate the kind of poetic achievement against which Collins, Gray, and Mason, as well as Warton, Blake, and Wordsworth, were reacting. 
It will be of value, then, to give some attention to these many poems: to describe the range of their subject matter, to outline the arrangement of their ideas, to examine the background from which they sprang, and to indicate what kind of need they fulfilled. The use of science and theology as topics for poetry has been understood in recent decades to be a perverse, if not contradictory, practice. Yet during the seventeenth century, as seen in the works of the so-called "Metaphysicals," religious experience provided a major portion of poetic matter. Much of the change in attitude during the past two centuries has been due to the changing image of science.

The history of science during the seventeenth century is well known. Scholars such as Burtt, Westfall, Barbour, and Harris have examined the metaphysical principles underlying the new science and have shown how these discoveries were understood by theologians to be compatible with--and indeed supportive of--traditional Christian doctrines. 3 Joseph Glanvill was only one of many religious writers who expressed unhesitating enthusiasm for the evidences of science. The "general heads" to the four sections of his book Philosophia Pia (1671) summarize this attitude:

(1) That God is to be praised for His Works.

(2) That His works are to be studied by those that would praise Him for them.

(3) That the study of Nature and God's works is very serviceable to Religion.

(4) That the Ministers and Professors of Religion ought not to discourage, but promote the knowledge of Nature and the Works of its Author.

This proposed harmony between science and religion was in fact achieved by such men as Ray, Wilkins, and Hooke, and especially by Robert Boyle, who founded a series of lectures designed to support Christianity with the evidences of science. The lectures for 1711 and 1712 were delivered by William Derham who published them in 1713 under the title, Physico-theology; or, A Demonstration of the Being and Attributes of God, from His Works of Creation. This popular book epitomized the tradition of harmony between science and religion because it led the reader from the "Works of Creation" to a fuller awareness of the "Power, Wisdom, and Goodness" of God (1727 ed., p. 427). A summary towards the end of the book describes God's care for mankind:

It appears throughout the foregoing Survey, what Kindness God hath shewn to his Creatures in providing every thing conducing to their Life, Prosperity, and Happiness; how they are all contrived and made in the best Manner, placed in the fittest Places of the World for their Habitition and Comfort; accouter'd in the best Manner, and accommodated with every Need, even all the minutest things that may minister to their Health, Happiness, Office, Occasions, and Business in the World ( $p$. 432-33).

As Sykes has pointed out, "to the pioneers of this nascent scientific movement, the works of God were at least of equal, if not of greater, importance than the record in his Word, as evidence of his character and 
purpose." 4 The created universe was generally accepted as sanctified; that is, it was understood to reveal some significant part of "the original harmony between man and the divine brought about by an act of grace, or sanctification."5 Sanctified nature was understood to be evidence of the divine plan and will; hence, Providential design was the dominant element in the order of the universe.

The universe became a rich area of exploration for both the scientist and the theologian, but it also attracted the attention of poets. They found in it material for describing the grand design of God and for delineating the nature of man. The rationale for this widespread impulse was clearly expressed by Richard Collins in the "Dedication" to his poem Nature Display'd (1727):

[The discoveries of ancient and modern Philosophers] are the Effects of various Labours, publish'd at different Times, scattered in the distant Compass of Essays, Theories, Transactions, \&c. so that very few have Application enough to peruse them; and perhaps, not Capacity enough, to fix upon such as are most useful to be known. I have, therefore, join'd to them my own thoughts; and to recommend them with the greater advantage, have endeavoured to put them into English Verse; and applied them to their proper Use, the promoting of Religion.

Collins's explanation emphasizes several elements which are central to the tradition of physico-theological poems. They are based upon, and justified by, scientific evidence. These works purport to describe in an objective way the actual operation of the universe (or some aspect of it) and to deduce from that operation by rational means certain equally objective and eternal moral truths. These truths of the physical and moral universe are made more comprehensible by verse. The same reasons apply here as applied to Pope's An Essay on Man:

This I might have done in prose; but I chose verse, and even rhyme, for two reasons. The one will appear obvious; that principles, maxims, or precepts so written, both strike the reader more strongly at first, and are more easily retained by him afterwards: The other may seem odd, but is true, I found I could express them more shortly this way than in prose itself.

The final result of expressing these "principles, maxims, or precepts" in this memorable and succinct manner is "the promoting of Religion." These poems are directly didactic in intent, and Warton was right in recognizing this. The element of didacticism is basic to all physico-theological epics. Jospeh Wise begins his mammoth poem, The System (1781)--planned for five books--with a statement of purpose similar to that of Collins:

Creation's scenes while, pensive, I survey, Where sot and sage with vague opinion stray; While, through the gloom, attentively I try To ken the truth with pure discerning eye; (Studious to fill my function as I ought; Inform'd to teach, as candid to be taught; And, for God's glory and man's good, make known The truth emerging, as expands the dawn). 
Capel Lofft opens Eudosia: or, A Poem on the Universe, a work in seven books also published in 1781, with a similar statement of purpose:

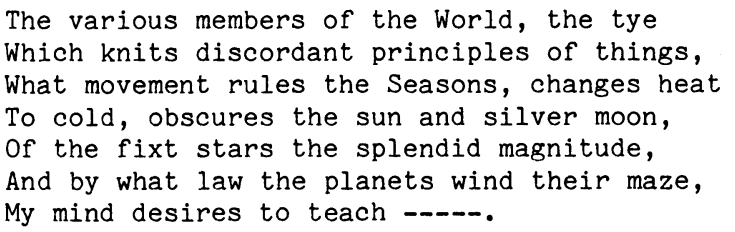

A wealth of physico-theological material had been built up in England by the 1720s. Pope's familiarity with, and manipulation of, this material has been studied by a number of scholars, 7 and Macklem has used it to illustrate the change in the climate of opinion from the time of Donne's Anatomie of the World (1611):

Both Donne and Pope were working within established schemes of belief. The prevailing assumptions within each were controlled by a theory of law and of the relationship between law and the natural and moral agent. For Donne this relationship is productive of disorder in both man and the world; for Pope it is productive of order. The difference is not simply that between affirmative and negative answers to the question of the existence of evil. It is rather that between a conception of evil as sin or the consequence of $\sin$ and a conception of evil as a condition of existence.

Macklem's theory is one way of explaining the implications of the changing concept of original $\mathrm{sin}$, and he is led to conclude that "by the middle of the century the idea set forth in the Essay on Man, that both moral and physical evil are inherent conditions of law, had become a literary common place." 9 But the change in the ontological status of evil did not come about in any clearly defined way, and the issues in science and religion which concerned the physico-theologians of the seventeenth century continued to concern the religious poets of the eighteenth.

As we have seen, the poets were writing within a tradition which had emerged as both central and controversial in eighteenth-century thought. Cragg has summed up the progress of this tradition:

... the seventeenth century held out high hopes that the insights of science and religion would be brought to fruitful reconciliation. The promise was not fulfilled. The succeeding generation was unequal to the task of integrating the new and the old. Our period ends with the curious spectacle of men who accepted with no sense of incongruity the $10^{\text {ncient }}$ stories of Genesis and the recent discoveries of Newton.

Not only did the physico-theological writers sense no incongruity between the words of Scripture and the works of Creation, they found positive harmony, and they also found what they understood to be objective evidence to refute unbelievers. In the Dedication to An Essay on the Universe (1739), Moses Browne claims he has described "an Artifice the many great PhysicoTheological Writers (such as Mersenne, the pious and noble Mr. Boyle, 
Cockburne, Bentley, Ray, and our late accurate and admir'd Mr. Derham) have been sensible of, when they have united in this successful Method of attack these detestable Enemies of Reason and Society." For justification in using physical ideas for poetry Browne turns to the authority of Fontenelle, whom he quotes as saying that "at the same Time they convince and satisfy the Reason, they present to the Imagination a Prospect, which looks as if it was made on purpose to please it." Later in the "Preface" to his poem he adds that "Considerations of this Kind (especially those suggested by Astronomy) enlarge the Mind, and raise in it higher Apprehensions and Reverence of the supreme Being." He expresses the same sentiments in the second book of his poem:

When with rais'd Eyes I view those Worlds above,
Engag'd in the same grateful Work of Love,
Let the grand Scene my solemn Art prepare,
And my Soul join a universal Pray'r. (11.449-52)

Writers of physico-theological works throughout the century saw themselves as belonging to the mainstream of public concern. Their subject matter had been approached by the finest sensibilities in both verse and prose, and while they were presenting eternal truth, they recognized that it needed to be expressed in contemporary terms. They explained their activity in ways similar to that of Collins. In the Introduction to Providence: An Allegorical Poem in Three Books (1764), John Ogilvie wrote, "From these observations on the nature of the human mind, the author of the following work was induced to form a plan for canvassing a subject, perhaps of all others the most interesting; in which philosophical sentiment might not be wholly separated from entertainment." Ogilvie recognized that "the difficulty of uniting ends so apparently remote, is augmented in proportion to the abstraction and subtlety of those ideas which are to be distinctly exhibited to the mind," but he hopes the critic will "regard the whole, if not as a work of the kind compleatly executed, yet at least as an attempt to introduce a species of composition, which may be found susceptible of the happiest improvements."

While these poets saw themselves as writing in a major literary tradition, they also felt that they needed to do so because of an important revolution brought about by the writings of John Locke on the topic of innate ideas. In the Preface to his Creation (1712) Blackmore explains this influence with great clarity. He begins his Preface by saying that "it has been the opinion of many persons of great sense and learning, that the knowledge of a God, as well as some other self-evident and uncontested notions, is born with us, and exists antecedent to any perception or operation of the mind." He goes on to confess his "inability to conceive this inbred knowledge, these original independent ideas, that owe not their being to the operation of the understanding, but are, I know not how, congenite and co-existent with it." In this opinion he was "afterwards confirmed by the famous author of the Essay on Human Understanding." However, he has not been forced to a conclusion of atheism, because, "supposing there is no inbred knowledge of a God; yet if mankind generally assent to it, whether their belief proceeds from their reflection on themselves, or on the visible creation about them, it will be certainly true, that the existence of a Deity carries with it the clearest and most uncontrollable 
evidence....." He points out that "it deserves consideration, that St. Paul, upon this argument, does not appeal to the light within, or to any character of the Divine Being originally engraven on the heart, but deduces the cause from the effect, and from the creation infers the Creator." In other words, because of the widespread rejection of the concept of innate ideas, Blackmore is here proposing the Works of Creation as the basis for determining the existence and will of God. Creation has been described as "a philosophical poem whose inspiration certainly lies in the paragraphs of Locke's Essay that deny an innate idea of God."ll The physico-theological epic developed, at least in part, in response to the need to account in terms other than those of innate ideas for the order of the universe. The poets founded their vision of a moral order, not upon inner light, but upon external evidence. This need to locate evidence for the existence and attributes of God on a basis other than the traditional one is the central impetus which determines many of the characteristics of these works.

The themes of physico-theological epics throughout the century are pretty much those of Pope's An Essay on Man as summarized at the conclusion of Epistle IV:

... I turn'd the tuneful art

From sounds to things, from fancy to the heart;

For Wit's false mirror held up Nature's light;

Showed erring Pride, whatever is, is right;

That Reason, Passion, answer one great aim;

That true Self-Love and Social are the same;

That Virtue only makes our Bliss below;

And all our knowledge is, Ourselves to know.

Underlying all these themes is the doctrine of Providence, the "grand design of God," as Patrides describes it.12 Ogilvie quite properly describes it as a "comprehensive" subject and so focuses each of the three books of Providence upon only one aspect: as it is seen in the Works of Nature, in Revelation, and in Human Life. His lengthy poem examines each of these in detail, and he is led to conclude that all evidence points to the operation of Providence:

Thus Wisdom speaks

To Man; thus calls him thro' th'eternal form

of Nature, thro' Religion's fuller noon, Thro' Life's bewildering mazes; to obseve

A Providence in All. (pp. 190-91)

Two years earlier William Mickle published Providence: or Arandus and Emilec. This poem claims to trace "the dark mysterious ways/Of Providence" and attempts to illustrate its operation in particular situations, as he explains in the Advertisement:

In the following Piece the Characters are chosen, sometimes from what we often see, and others from what has sometimes been. To bring about the Deliverance of distressed Innocence, by a chain of the most surprising events, is the way of our Novel Writers, and 
has a great influence on striking the Fancy: but as there are seldom or never such things in reality, and as it was the intention of this juvenile Essay, to show the Justice and Care of Providence in common events, so these events are not brought about by uncommon means....

Samuel Hayes, in his Seatonian poem Creation (1784), claims that the Muse may assist in enlightening the reader on this topic:

\begin{abstract}
If as she pours the Verse, and vindicates
The ways of Providence, a ray of light

Dart on th'unconscious breast, if only one, Whom error hath seduc'd, or the dark arts of subtle infidelity ensnar'd. (p. 2)
\end{abstract}

The basic problem in explaining the ways of Providence is, as Pope recognzed, to account for the existence of evil. Francis Gentleman, in Characters: An Epistle Inscribed to the Earl of Carlisle (1766), suggests that "Wishes which kindly Providence denies,/ Teaching, by disappointments, to be wise" ( $p .10$ ) are really wishes which are not requisite for our happiness. However, most writers attempted a more complex explanation than this. Some, like Gentleman and the anonymous author of Divine Wisdom and Providence (1736) said their works were directly "occasioned by the Essay on Man." This latter poem accepts the fallen nature of man (a topic subtly avoided by Pope) but suggests that we can still conceive perfection:

Search your own Mind, and from Impressions there, Discern what his Divine Perfections are;

This broken Mirror, still reflects the Light, Which shows us, all from Him is good and right. (p. 16)

Ogilvie expresses the purpose of Providence in similar terms:

To clear the ways of providence, as far

As Reason scans them, and unfold to man

That perfect Beauty is their glorious End. (p. 12)

In his later poem Paradise (1764) Ogilvie describes an ideal world where "Art moulds the plan by forming Nature wrought" (p. 5). But to many eighteenth-century writers their world was clearly distinct from an ideal, and this discrepancy had to be explained. The doctrine of man's fall remained an important part of the intellectual climate of the age in spite of the popularizations of the doctrines of Shaftesbury.13 The change effected by the fall provides the central focus of Abraham Portal's Innocence (1762):

\title{
Universal Peace
}

Throughout the Air, Earth, Sea, smil'd harmless; whilst

Enraptur'd Man, not yet of fending, reign'd

Sole Lord of all, in Happiness complete;

But oh! he fell: from thy Dominion calm

Rashly with-drawing, and with him soon join'd

Revolting Nature. (p. 14) 
How to accommodate happiness to this fallen state is a problem for man. In trying to resolve it, John Duncan in Letter III to An Essay on Happiness (1762) says that "the permission of sin to take place among the creatures of an infinitely wise and good deity, and the judicial blindness consequent upon it, and prevailing to so great a degree almost over the whole race of mankind, are subjects, about which it becomes us always to speak with the utmost caution and reserve" ( $p .14)$. His resolution is to proclaim "a present God":

On all sides pressing on thy raptur'd Sense Behold the Sov'reign Cause of boundless good Smiles in the vernal blossom's lively blush. (p. 93)

William Hay in The Immortality of the Soul (1754) adopts a similar solution and in so doing recognizes that he differs from Pope:

Well sings our bard, 'whatever is, is right.'

But neither right nor just, if constant woe

Attend the good, and vice triumphant go.

He suggests that man should, "Parts single, not the system vast, survey" (p. 28), and therefore find the perfection that "dwells within the breast" (p. 39). The anonymous author of An Essay on Immortality (1760) addresses these same issues, and asks, "Where mighty Pope and Addison can fail/ How little will my artless Notes avail?" He turns to Reason as the vehicle to overcome the damage of evil: "Our Reason still can boast her sov'reign Pow'rs" (p. 4).

Other poems, such as The Universe (?1727) by Henry Baker, emphasize the need to curb man's pride and to recognize that man is only "One single Link of Nature's mighty Chain" ( $p$. 33). Samuel Hayes in The Exodus (1785) also attacks "the arrogance of forward Man" ( $p$. 14). If man can maintain his proper station, he can achieve the true merit, "that Angels Love, and Mortals reach below" as Henry Jones put it in Merit (1753), or what Duncan described as real happiness.

The matters of Providence, of evil, of pride, and of virtue are all aspects of the poet's attempt to express his vision of a supernatural harmony and order. Admittedly, "mysterious are the ways of Heaven;/ God's counsels dark" ( $p .21$ ), as William Roberts put it in A Poetical Essay on the Existence of God (1771), but his faith in a meaningful order is firm. He directly attacks the mechanistic views associated with Leibnitz and the atomistic views associated with Lucretius. His own views are unambiguously providential:

He, mighty God, whose providential eye

Looks down upon the meanest of his works,

'Midst every natural, every moral ill,

Preserves the human race. (p. 10)

This quotation, in fact, might well be taken as a rubric for all of the physico-theological epics and especially for James Thomson's The Seasons $(1726-30)$, part of whose purpose is precisely to delineate particular providence. Although it has been suggested that in the poem "there is no 
necessary harmony between nature and man or within nature,"14 the seasons do "represent a form of divine order; they are thoroughly appropriate as a structure for glorifying God through His works--and the glorification of God is perhaps the primary motive for The Seasons, "15 as it is the primary motive for all physico-theological epics.

In addressing themselves to the issues of science and religion, eighteenth-century poets were deliberately dealing with what they regarded as meaningful and relevant subject matter, a subject matter which had proved of major concern for centuries. The popular reception of these poems is somewhat difficult to gauge. Samuel Johnson praised The Creation, of fered qualified approval of Night-Thoughts, and described The Excursion as an imitation of The Seasons. He devoted considerable attention to a criticism of this poem in his biography of Thomson, as did John More in his Strictures, Critical and Sentimental, on Thomson's "Seasons" (1777). Pope's Essay on Man and Young's Night Thoughts elicited a number of direct responses, such as Bridges' Divine Wisdom and Providence: An Essay Occasion'd by the "Essay on Man" (1736) and William Ayre's Truth: A Counterpart to Mr. Pope's "Essay on Man" (1739), and the anonymous works The Vindication: Or, Day-Thoughts on Wisdom and Goodness; Occasioned by The Complaint (1753) and Religious Conscience: Or, the Morning and Evening Sacrifice; A Poem in Imitation of Dr. Young's Night Thoughts (1755). Thomson's The Seasons was also well-known. Even Duncan's An Essay on Happiness (1762) achieved an enlarged second edition in 1772. Roberts' Poetical Essays were originally published separately in 1771 and were reprinted in a new edition of his Poems (1776). Even Wise's The System received notice ("a very long and laborious work") in the Critical Review (1782). There is adequate evidence to guess that this tradition of physico-theological epics remained sufficiently wide-spread throughout the eighteenth century to represent a major poetic force against which the so-called "Romantics" felt they needed to rebel.

In the revolutionary and historically important Essay on the Application of Natural History to Poetry (1777) John Aikin basically approved the study of Nature:

That this study is not only a source of agreeable and innocent amusement, but conduces to humanize and enlarge the mind, and in various ways to promote the happiness of mankind, has been sufficiently proved by the observation of many ingenious writers.

His high praise of Thomson and his concern with imagery which presents "minuter distinctions and mutual relations" may mark a major change in poetic taste, but, like "many ingenious writers" before him, he was fully aware of the importance of the physico-theological tradition for English poetry. 
NOTES

1 Hoxie Neale Fairchild, Religious Trends in English Poetry, II (New York: Columbia University Press, 1942); William Powell Jones, The Rhetoric of Science: A Study of Scientific Ideas and Imagery in Eighteenth-Century English Poetry (London: Routledge, 1966); $\mathrm{H}$. Grant Sampson, The Anglican Tradition in Eighteenth-Century Verse (The Hague: Mouton, 1971).

See in particular C.S. Lewis, A Preface to Paradise Lost (London: Oxford University Press, 1942); J.B. Broadbent, Some Graver Subject (New York: Barnes and Noble, 1960); A.D. McKillop, The Background of Thomson's "Seasons" (Minneapolis: University of Minnesota Press, 1942); Patricia Spacks, The Varied God (Berkeley: University of California Press, 1959); Isabel St. John Bliss, "Young's Night Thoughts in Relation to Contemporary Christian Apologetics," PMLA, 49 (1934), 37-70.

Richard S. Westfall, Science and Religion in Seventeenth-Century England (New Haven: Yale University Press, 1958); Ian G. Barbour, Issues in Science and Religion (New York: Prentice-Hall, 1966); Edwin Arthur Burtt, The Metaphysical Foundations of Modern Physical Science (New York: Harcourt, Brace, 1925); Victor Harris, All Coherence Gone (Chicago: University of Chicago Press, 1949).

Norman Sykes, The English Religious Tradition (London: SCM, 1953), p. 53 .

H. Grant Sampson, "The Sanctification of Nature," Religion in the 18th Century, ed. R.E. Morton and J.D. Browning (New York: Garland, 1979), p. 93.

"The Design" to An Essay on Man. For a discussion of this topic by James Ralph, see the Preface to Night (1728), pp. iii-x.

See, in particular, Geoffrey Tillotson, Pope and Human Nature (Oxford: Clarendon, 1958); Martin Kallich, Heav'n's First Law: Rhetoric and Order in Pope's "Essay on Man" (Dekalb: Northern Illinois University Press, 1967); Douglas H. White, Pope and the Context of Controversy: The Manipulation of Ideas in "An Essay on Man" (Chicago: University of Chicago Press, 1970).

Michael Macklem, The Anatomy of the World (Minneapolis: University of Minnesota Press, 1958), p. 4.

Macklem, p. 63.

10 Gerald R. Cragg, From Puritanism to the Age of Reason (Cambridge: Cambridge University Press, 1950), p. 229. 
11 Kenneth MacLean, John Locke and English Literature of the Eighteenth Century (1936; rpt. New York: Russell and Russell, 1962), p. 31 .

12 C.A. Patrides, The Grand Design of God (London: Routledge, 1972).

13 Cecil A. Moore, "Shaftesbury and the Ethical Poets in England," PMLA, 31 (1916), 264-325.

14 Ralph Cohen, The Unfolding of The Seasons (Baltimore: Johns Hopkins University Press, 1970), p. 328.

15 Spacks, p. 22. 